\title{
Mimicry and East-West Hybridity in Najīb Al-Kïlaniy's Ar-Rajulul-Ladzī Āmana: A Postcolonial Literature Study
}

\author{
$1^{\text {st }}$ Sangidu $1,2^{\text {nd }}$ Harun Joko Prayitno $2,3^{\text {rd }}$ Sherif Sa'ad El-Jayyar ${ }^{3}, 4^{\text {th }}$ Hassan Youssef $^{4}, 5^{\text {th }}$ Awla \\ Akbar Ilma ${ }^{5}$ \\ \{sangidu@ugm.ac.id ${ }^{1}$, harun.prayitno@ums.ac.id ${ }^{2}$, dr.shariefaljayyar@yahoo.com $^{3}$, \\ youssef@gmail.com ${ }^{4}$, awlaakbar24@gmail.com ${ }^{5}$ \} \\ Intercultural Department Faculty of Cultural Sciences Universitas Gadjah Mada Yogyakarta ${ }^{1}$, Faculty of \\ Teacher Traning and Education Universitas Muhammadiyah Surakarta ${ }^{2}$, Faculty of Arts Bany Suef \\ University, Egypt ${ }^{3}$, Faculty of Arts and Humanities, Suez Canal University, Egypt ${ }^{4}$, Faculty of Arts and \\ Humanities, Suez Canal University, Egypt ${ }^{5}$
}

\begin{abstract}
East and West are two cultural forces that establish contact and influence each other. This condition makes possible the emergence of cultural change (mimicry) and the mixture of Western and Eastern culture (hybridity). As such, questioning the assumption that the West is always superior while the East is inferior is relevant. This study aims to uncover the mimicry and hybridity of Eastern and Western cultures in Najīb al-Kīlāniy's novel Ar-Rajulul-Ladzī, represented by the characters Iryan (Abdullah Carlou), a Christian musician from Rome, and Syamsi, a Muslim singer from Dubai. Postcolonial theory, which seeks to uncover the influences of colonialism on the culture of colonized society, is used to analyze and reveal the two cultures. For this study, the method involved recording data relating to Eastern and Western cultures through the ideas and behaviors of the characters in the work. This research shows that Eastern culture is not as weak or inferior as portrayed in colonial literary works. It has a strong identity and can also influence Western culture, as shown in the ideas and behaviors of the characters in the novel Ar-Rajulul-Ladzī Āmana.
\end{abstract}

Keywords: ar-rajulul-ladzī āmana, hybridity, mimicry, postcolonialism, postcolonial literature.

\section{Introduction}

As widely known, Western - primarily European - countries colonized many other areas, including areas in Asia, America, Africa, and the archipelagos of the world. This era of colonialism lasted from the 15th century CE through the late 19th and early 20th centuries CE (Abul-'Azm, 2015:3).

In Arab/African countries, European colonialism lasted from the 19th century through the 20th century CE. In 1798 CE, for example, Egypt was occupied by the French army under Napoleon Bonaparte. Three years later, the French were driven out by joint English-Turkish forces, and in 
1882 CE Egypt was colonized by the English. In 1922 CE, Egypt gained its independence, but remained under European supervision as an English protectorate. In $1911 \mathrm{CE}$, Libya fell to the Italians. In the early 20th century CE, Kuwait and Iraq were under English occupation. European colonial forces continued to assert their power throughout the region, from Libya, Dubai, Kuwait, Tunisia, Algeria, Beirut, Syria, Morocco, through Egypt. They seized fertile land from its owners the Arab people themselves. They showed no hesitation, even, in destroying the economic foundations and agriculture of the lands they were occupying. They used cruelty and brutality, with undertones - or overtones - of racism, to impugn upon the rights of the indigenous peoples and force their desires upon them, to humble, subdue, control, and fight those under their power (Abul-'Azm, 2015:9-10).

In 1948 CE, Zionists founded the state of Israel on Palestinian land, leading to the widespread migration of Jews (particularly European Jews) to these lands. As such, Jews and Israeli forces began occupying Palestinian lands. These lands were taken from their rightful owners, who were massacred by Israeli forces. The Israelis were led by Aragon Jews, armed by Zionists, and backed by English forces. Terrified Palestinians fled their land and abandoned their possessions, hoping to save themselves from the deadly Israeli assault. They established refugee camps throughout southern Lebanon, Jordan, and Syria. The Palestinian people became fragmented, while Palestinian lands laid empty. Israel, thus, could easily enter the lands and gain control of them. The Israeli attacks lasted into the mid-20th century CE, and the Zionists felt that they had the right to use the Palestinian lands that had been abandoned by their true owners (Abul-'Azm, 2015:10).

From such a colonial background emerged such famed writers as Taufĩq al-Chakīm (1897 CE - 1987 CE), Thahā Husain (1889 CE - 1973 CE), Mushthafā Luthfy Al-Manfalūthy (1876 CE 1924 CE), Abbas Mahmud al-‘Aqqad (1889 CE - 1964 CE), Ibrahim Abdul Qadir al-Mazini (1889 CE - 1949 CE), Mahmud Taymur (1894 CE - 1974 CE), Najīb Machfūzh (1911 CE - 2006 CE), Nizar Taufiq Qabbani (1923 CE - 1998 CE), Ghassān Kanafāniy (1936 CE - 1972 CE, killed by Mossad), Mahmud Darwisy (1941 CE -2008 CE), and Najīb Al-Kīlāniy (1931 CE - 1995 CE), etc.

Najīb bin Ibrahim bin 'Abdul Lathīf Al-Kīlāniy was born in Shirshabab, part of the Arab Republic of Egypt. From his youth, he was taught by his grandfather to memorize the Qur'an. Upon reaching adulthood, he enrolled at the Faculty of Medicine, Fouad I University (now Cairo University). During the course of his studies, he did not only focus on medicine, but also became involved in practical politics. As a result, he was arrested on 8 July $1955 \mathrm{CE}$, while still a student, and detained until he was released in 1957. After his release, he continued his studies, finally graduating in 1960 and becoming a company doctor. In 1967, as the political situation in Egypt became increasingly unsafe, Najīb moved to the United Arab Emirates and found work as a doctor in Dubai (Al-Kīlanniy, 2006). While still working as a doctor, he produced 35 novels as well as numerous academic works. Among these novels is Ar-Rajulul-Ladzī Āmana (A Faithful Man).

Ar-Rajulul-Ladzī Āmana explores how the East and West mutually influence each other in the postcolonial era. Najīb al-Kîlaniy presents the West through Italy (Rome), as represented by the characters Iryan (Abdullah Carlou), Sophia (Iryan's lover), Benito (Iryan's bandmate), Carlou (Iryan's father), and Iryan's mother. Meanwhile, the Eastern culture of Dubai is represented through Syamsi (a 25-year-old Muslim dancer and singer), Ali (a Muslim tour guide who takes Iryan around Dubai), Saqar (a young entrepreneur and merchant in Dubai), Sheikh Jalaluddin (the sheikh of a large mosque in Dubai, who discusses many elements of Christianity and Islam), Sheikh Idul Husain 
(the Sheikh of Al-Kaz Mosque and a teacher of Islam), Sheikh Abdul Ya'qubi (a man who teaches Islam to Iryan), and Maisun of Syria (a woman who is betrothed to Iryan) (al-Kīlāniy, 2001).

Furthermore, the novel Ar-Rajulul-Ladzī Āmana depicts the mimicry of Eastern culture, as exhibited by the Italian character Iryan (Abdullah Carlou), as well as the hybridity of East and West, as seen through the character Syamsi, a Muslim singer from Dubai. Eastern and Western culture mutually influence each other over the course of their existence. The mutual influence of Eastern and Western culture through transformation (mimicry) and mixing (hybridity) is a serious topic that requires further exploration (Sulistyorini, Sudardi, Warto, 2017).

Research into this subject shows that Eastern culture is not as weak and backwards as frequently depicted in Western literature. Eastern culture is strong and firm, capable not only of surviving but also of influencing and transforming western culture. It can be seen that both Western and Eastern cultures influence each other (Chen, 2014; Lu, 2001; Moriguchi, Evans, Hiraki, Itakura, \& Lee, 2012).

Several previous studies have examined the connection between East and West using a postcolonial perspective, including the contestation of modernity and tradition in colonial-era Indonesian poetry (Suyatno, 2012), the opposition of the punakawan to Othering through cultural mimicry and hybridity in the novel Puragabaya (Afri Wita, 2013), the dialectics of Indonesian and Western cultural identities at the global level (Kasiyan, 2003), and the relationship between Indonesian literature and Balai Pustaka-era translations of European literature (Prasojo, 2015). Meanwhile, postcolonial studies of Middle Eastern literature have included studies examining the imaginations of West and East in novels published in Israel and Palestine (Daniel Carnie, 2019), migration from conflict-prone Afghanistan to the security of the United States in the novel The Kite Runner (Shabrina, 2014). In these studies, West and East are always positioned as having an antagonistic relationship, one of dominance and resistance, of competition and opposition.

\section{Approach and Method}

Discussion of postcolonial literature cannot occur without an understanding of colonial literature. Works of colonial literature are those literary works produced by Western authors which present racist and antagonistic views of the Eastern world and its inhabitants. Such literature was frequently written in English or in French to further the interests of Western colonial powers. Western authors deliberately shaped understandings of colonial expansion through the literary works they produced. As such, works of colonial literature consciously depicted the peoples of colonized Eastern lands as backwards, weak, and barbarian. Building on these depictions, they concluded that Western civilization was the most advanced and noble of the world's cultures, thereby marginalizing Eastern civilization (Abul-'Azm, 2015:8).

As such, in the postcolonial era many works of literature were published in the languages of colonized and once-colonized lands. These postcolonial works of literature, including prose, poetry, etc., were used by the residents of these former colonies as media and means for urging opposition to colonialism. Works of postcolonial literature also urged readers to seek out their own identity, be it ethnic, cultural, or national, enabling the East to narrate itself and present its true face to the West. 
Postcolonial literature also challenged the racism inherent to Western literature's exploration of the east (Abul-‘Azm, 2015:7).

In postcolonial literature, the Eastern world has also criticized and evaluated itself. Writers of postcolonial literature have shown the faults of the Eastern world, its shortcomings, its weaknesses, its helplessness, and its inability to properly resist decades or even centuries of colonialismdespite, before the erasure of its identity by Western colonialism, its ability to conquer the world. There was a paradox, distinguishing between the East as a land of weak and backwards culture, of uncivilization, and the West as a land of strong culture and civilization. Furthermore, the West viewed the East through a weakening and racist gaze. As such, postcolonial literature began promoting nationalism through the reassertion of a lost eastern identity and resurrection of precolonial glory. The stories in postcolonial literature, it was hoped, could spread a nationalist fervor and inspire readers (Abul-'Azm, 2015:3).

Postcolonial literature is literature that was born and exists within countries and nations that have experienced colonialism, be it written by authors from colonizing nations (in English or French) or by authors from colonized nations (in a language of their nation, such as Arabic) (compare Abul-'Azm, 2015:11).

As stated above, this article will examine the cultural mimicry and hybridity within the novel Ar-Rajulul-Ladzī Āmana. Mimicry refers to cultural transformation and the imitation of existing culture. Mimicry can be understood as a sign of a colonized nation's opposition to and avoidance of the colonizing state' attempts to dominate others by normalizing a specific knowledge, behavior, and situation (Bhabha, 1994:86). In colonial and postcolonial literature, mimicry is often evidenced in the colonized people's imitation of the colonizing nation's language, clothing, politics, or cultural behavior in order to oppose or avoid subjugation (Singh, 2009:1). Meanwhile, hybridity refers to the mutual influence of different cultures. It may be said that hybridity involves the mixing of two ideas from different cultures, namely the indigenous culture of the East and the imported culture of the West, but with the origins of these ideas still remaining distinguishable. Hybridity may be understood as the changing of culture through the mutual influence of the cultures of the colonizer and the colonized. In other words, the culture of the colonizer (West) can influence the culture of the colonized (East); conversely, the culture of the colonized (East) can influence the culture of colonizer (West). The possibility that these cultures can influence each other implicates that they are equally strong (Ray, 2014:125).

To analyze postcolonial Arabic literature, in this case the novel Ar-Rajulul-Ladzī Āmana, the observation method - a detailed and repeated reading of the work from its first to its last page - has been used to understand the contents of the novel being studied. To focus on the formal object, specifically cultural transformation (mimicry) and mixing (hybridity), the expression technique has been used to reveal textual data on mimicry and hybridity as seen in the ideas and behaviors of the characters. All collected data has been analyzed before conclusions were drawn.

\section{Results and Discussion}

To explore the mimicry and hybridity of Eastern and Western culture in the novel Ar-RajululLadz̄ $\overline{\mathbf{A}}$ mana, it is necessary to first reveal the two cultures being discussed. Eastern culture is that 
culture that originates from Eastern societies, in this case the people of Dubai, as represented by Syamsi and other characters, while Western culture is that culture which originates from Western societies, in this case the people of Rome (Italy) and represented by Iryan (Abdullah Carlou) and other characters. Eastern and Western culture are manifested in the work through the ideas and behaviors of these characters.

\subsection{Cultural Mimicry}

As mentioned above, mimicry refers to the transformation of cultural forms and imitation of existing cultures. These cultural transformations and imitations may be manifested through ideas and behaviors (Maeda, 2009). In the novel, Western cultural ideas and behaviors are represented by the character Iryan (Abdullah Carlou). A famed musician of Italian heritage, Iryan's ideas have been influenced by the everyday life and behaviors of his father, Carlou, an influential pastor. As part of his work, Carlou spends his days teaching Christians to do well and to always remember God. These Christian ideas were similarly conveyed to Iryan from childhood, and he attempted to practice them. However, as part of his musician lifestyle, Iryan often drank alcohol, acted frivolously, and spent his nights in a café or bar while enjoying the Italian music scene (al-Kīlāniy, 2001). As such, Iryan may be seen as manifesting Western (Italian) culture, as seen below:

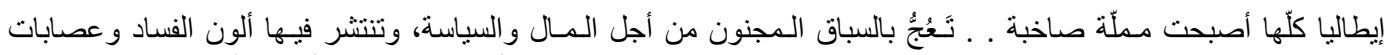

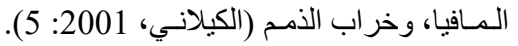

Translation: Italy, a place where people collected their possessions with euphoria and competed crazily to seize material wealth and (political) power. All types of debauchery and degradation, of mafia and violence, and criminal enterprise could be found throughout Italy (alKīlāniy, 2001:5).

From this textual evidence, it may be concluded that Western - particularly Italian - culture is depicted through the characters' behavior as oriented towards individual freedom. Westerners seek power using any means available, and collect as much material wealth as they can to ensure their worldly pleasure. Enmity is a common result, and various mafias exist to seize the available opportunities. When they break the law, they simply pay to ensure their problems disappear. In short, the behavior of society is depraved and debased. People act as they please, seeking to advance their own individual interests and find worldly pleasure.

Seeing the increasing decadence and degradation of Italian culture, Iryan (Abdullah Carlou) decided to seek out another world, one in which he could find enlightenment and peace as a musician. As such, Iryan decided to travel to Dubai to hold a concert, seeing the city as one of the "Diamond of the Bay", the most beautiful city in the bay area. Before traveling to Dubai for the concert, however, Iryan was heartbroken to think of his beloved Sophia. Sophia was unwilling to travel to Dubai, and even after Iryan offered to marry her before the trip, Sophia refused; she wanted to continue having fun. This is shown in the following textual evidence.

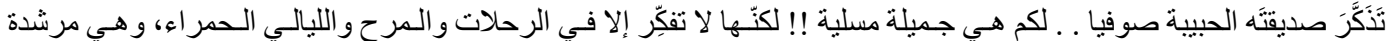

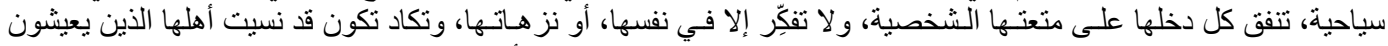

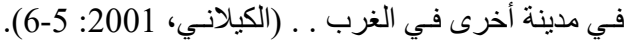


Translation: Iryan remembered his beloved girlfriend, Sophia. Truly Sophia was a beautiful and pleasurable woman! But Sophia only thought of travelling, of having fun, even though she was a woman of education. Sophia spent all of her income, her wages, on bringing joy to herself. She only thought of herself or had fun for herself. She almost forgot about her family, those living in western Italy (al-Kīlāniy, 2001:5-6).

From the textual evidence above, it can be concluded that Sophia was reluctant to travel to Dubai with Iryan, and to marry Iryan as well, because she found it more important to continue her Western practices of having fun with her male friends, drink beer in the pub, and travel wherever she pleased. She maintained this view even though, for a single concert in Dubai, Iryan would receive no less than USD 3,000; his accommodations, consumption, and transportation costs would also be covered. As such, the amount he received would be more than enough for Iryan and Sophia to live on in Dubai. However, Sophia cared little for this, prioritizing her own pleasure over her life with Iryan. As such, Iryan traveled to Dubai for his concert with a broken heart, and he felt himself overwhelmed by doubt after having separated with his beloved girlfriend Sophia. It is in this state of mind that Iryan remembered the advice he had received from his father: "Iryan, my son. Know that the most abundant possessions and the strongest weapons wielded by those in power will never be able to protect those wandering souls, but they will be able to defend those with calm souls, healthy minds, soft voices, and good behavior. Because of that, control yourself, and you will be able to rule the world" (al-Kīlāniy, 2001).

Upon arriving at the Dubai airport, Iryan was picked up by Ali, a tour guide and public relations staff member who was tasked with handling the details of Iryan's trip and concert, as well as ensuring that Iryan's needs were met. Iryan found the city of Dubai to be beautiful, with clean streets, polite women, safety and security at all levels of society, and prohibition against drinking alcohol (khamer); this left him with the impression that the people of Dubai lived noble lives and had pure souls. One of the items on his itinerary was watching an "eastern dance"; he also desired to sing songs in an eastern manner. At the concert venue, Iryan waited for a beautiful Muslim singer and dancer named Syamsi. When this daughter of Dubai came on stage, people shouted "Syamsi... Syamsi... Syamsi..."; Iryan soon found himself calling her name as well. Syamsi began her graceful dance, and Iryan found his fingers dancing along, playing an invisible piano to the rhythm of Syamsi's movements. Syamsi's red face was beautiful, complemented by her tall frame and her long black hair, and Iryan found himself lost in Syamsi's dance. After the end of the concert and dance recital, Iryan returned to his hotel room and laid in bed. Every night, Iryan found himself unable to sleep, haunted by the beautiful face of Syamsi dancing within his heart. This anxiety suggested that Iryan had fallen in love with Syamsi, and he decided that he needed to convey his love to Syamsi and ask her to marry him (al-Kīlāniy, 2001). This is shown by the following quote:

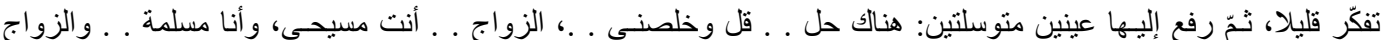

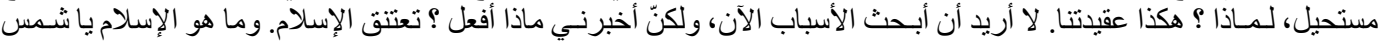

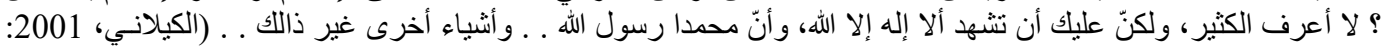
.(27-25

Translation: Iryan thought for a moment, then lifted his eyes to look into Syamsi's as he said: "There's a place. Say the word and ask me with you." ... Iryan answered: "Marriage." (Syamsi replied): "You're a Christian, and I'm a Muslim. We could never marry". Iryan asked: "Why"? 
Syamsi answered: "That is our religious principle and teaching." Iryan said: "I don't want to talk about the reasons now... just tell me what I need to do." Syamsi answered: "Become Muslim." Iryan asked. "Yes, Syamsi. What is Islam?" Syamsi replied: "I don't know much. But what you need to do is speak the two sentences of the Shahadah, bear witness that there is no God save Allah, and that the Prophet Muhammad is the emissary of Allah. There are also some other things, aside from those two sentences (al-Kīlāniy, 2001:25-27).

This textual evidence shows that Iryan could not bear to wait any longer, for so strong was his love for Syamsi. He gazed deeply into Syamsi's eyes, and she understood that he loved her. Syamsi agreed to meet Iryan, and Iryan asserted that he would marry Syamsi. However, Syamsi was surprised by the word "marriage", saying that they could not marry because Iryan was a Christian while Syamsi was a Muslim. Such interfaith marriages are prohibited according to Islamic teachings; Iryan and Syamsi could only marry if Iryan became a Muslim and embraced the Shahadah.

Iryan's deep love for Syamsi meant that he would do anything to realize his desire to take Syamsi as his wife. Iryan did not want to waste any time. As such, Iryan decided to study Islam. He asked the tour guide, Ali, who gave him the name of a religious scholar who could teach him about Islam.

\section{Iryan Studying Islam under Sheikh Jalaluddin}

Iryan felt anxious because he wanted to learn the true meaning of Islam. As such, he asked Ali, his trusted tour guide. He knew that Ali was an honest tour guide, one who could be trusted, and a person who sought to fulfill Iryan's needs. Iryan asked Ali, "What is Islam?", and Ali answered that, to know the teachings of Islam and their contents, it would be best for him to meet with a religious scholar named Sheikh Jalaluddin (the sheikh of a large mosque in Dubai). This is shown in the following quote:

\footnotetext{
"بالتأكيد . . ما الإسلام يا علي ؟ أل لايك كُتُبا بالأنجليزية ؟ أستطيع أن أدبر ها للك، بشرط أن تعطيني فكرة كاملة عن الإسلام.

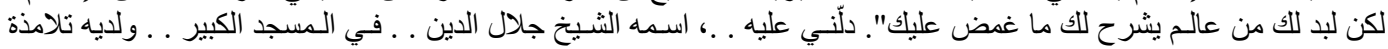

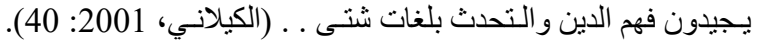

Translation: "Mr. Ali, what is Islam? Do you have any books about Islam in English?" Ali answered: "I can prepare some for you." "Good," answered Iryan, "as long as it can provide a whole picture of Islam." Ali answered, "Of course, gladly. But you must have someone who can guide you, who can help you understand what is in your heart and what is troubling you..." "Show me him." "His name is Sheikh Jalaluddin... at the Grand Mosque... he has students who truly have a deep understanding of Islam, who can speak and explain things in various languages" (al-Kīlāniy, 2001:40).

This textual evidence shows that Iryan met with a religious scholar who showed him the true meaning of Islam and taught him how to practice it. Iryan felt happy, as Sheikh Jalaluddin spoke and taught him in Islam. At first, Iryan and Sheikh Jalaluddin discussed many elements of Christianity and Islam, recognizing Iryan's Christian background. Iryan tried as hard as he could to overcome the difficulties he faced, as from youth he had been taught about Christianity by his father, who was a pastor in Rome. Later, Benito - one of Iryan's musician friends - asked him why he was studying Islam and chose to convert. Was it merely because Iryan had fallen in love with a Muslim, 
the Dubai-born singer and dancer Syamsi? Or did Iryan have another reason for converting to Islam? Iryan answered Benito's questions by saying that he was not converting to Islam because he had separated from Sophia, his Christian girlfriend in Rome, and not because he had fallen in love with a Muslim woman named Syamsi, but because he was seeking a "truth" that brought peace to his heart. During their meetings, Iryan and Sheikh Jalaluddin could frequently debate, discuss, and exchange their thoughts on Christian and Islamic teachings, such that Iryan ultimately understood that the teachings of Islam were perfectly suited for him. Afterwards, Ali the tour guide agreed to bring Iryan to meet another religious scholar, Sheikh Idul Husain, who could help him gain a deeper understanding of Islam and how to practice it (al-Kīlāniy, 2001).

\section{Iryan studying Islam under Sheikh ‘Idul Husaini}

Iryan did his best to learn the truth of Islam not because of his lost love for the lovely woman Sophia, a Christian in Rome, and not because he found himself falling in love with a beautiful Muslim singer, but because these loves had made him recognize the need for a truth that could heal his heart and give him peace even in the face of adversity. As such, Iryan met with Sheikh Idul Husain (the sheikh of Al-Kaz Mosque), a scholar who could teach him Islam, as seen in the following quote:

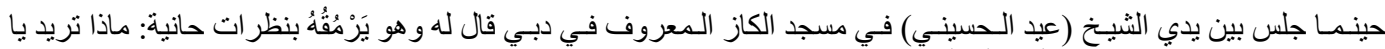

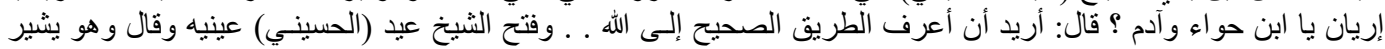

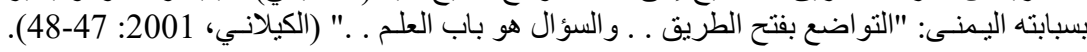

Translation: When Iryan sat before Sheikh ('Idul Husaini) at the famed Al-Kaz Mosque of Dubai, the sheikh looked at him calmly, showing his interest, and asked: "What do you want to ask, Iryan, son of Adam and Eve?" Iryan answered: "I want to know the true path to Allah..." Sheikh 'Idul (Husaini) opened his eyes and said, while pointing with his right finger, "Tawadhu', humility, that will open the path to truth. ... And asking questions is the door to knowledge..." (al-Kīlanniy, 2001:47-48).

This textual evidence indicates that Iryan's meeting with the sheikh cemented his faith in Islam, as Iryan was able to ask the sheikh questions about his problems and about the teachings of Islam. Sheikh 'Idul Husaini was a famed scholar, a charismatic man with white skin, a red turban, thick beard, and clear eyes that radiated a calming light. Meeting the Sheikh, Iryan became increasingly certain in his quest to find the true path to Allah. One lesson that Sheikh 'Idul Husaini taught was tawadhu', the humility expected of all Muslims, with which Muslims could find the way to truth. Furthermore, Iryan asked Sheikh 'Idul Husaini many questions, as he had a deep thirst for knowledge about Islam. Time and time again, Iryan and Sheikh 'Idul Husaini discussed various elements of Islam and how to practice its teachings. He later asked Ali to help him meet with other sheikhs, thereby guiding him on his journey to find the truth and to eliminate doubt. As a professional tour guide, Ali invited Iryan to meet Sheikh 'Idul Ya'qubi to ensure he was truly certain about the teachings of Islam and was able to practice these in his everyday life. 


\section{Iryan Studying Islam under Sheikh 'Idul Ya'qubi}

One day, Iryan attended a meeting for persons seeking to gain knowledge about Islam. At such meetings, it was common for students - both new and old - to be greeted by the sheikhs and thereby ensure good relations between them; this was hoped to ease the teaching process. Sheikh 'Idul Ya'qubi was famed as a teacher with expansive knowledge, as well as the capacity to convey said knowledge to his students. The following quote describes the atmosphere at the meeting led by Sheikh 'Idul Ya'qubi:

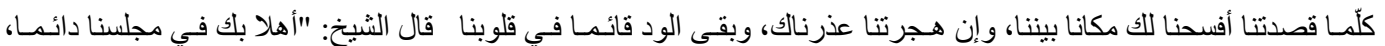

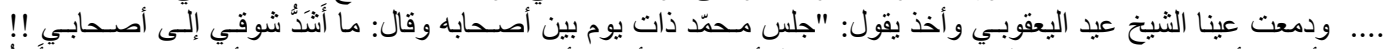

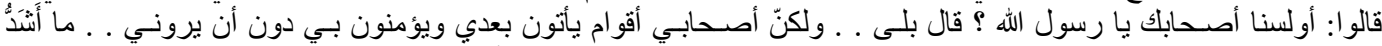

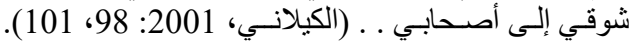

Translation: The Sheikh said: "Welcome to our meeting. Every time you come, you will surely find a place for yourself. And if you leave us, we will miss you. May love forever remain in our hearts."

Both of Sheikh 'Idul Ya'qubi's eyes shone, then he said: "One day, the Prophet Muhammad sat among his companions and said, 'Oh, how I long for my companions!' His companions then replied, 'Are we not your companions, oh Prophet?' The Prophet answered: 'This is true, but my companions who come after my death and believe in me without seeing me, how I long for them'." (al-Kīlāniy, 2001:98, 101).

This textual evidence shows how Sheikh 'Idul Ya'qubi welcomed all those who came to the meeting, including Iryan. For those students who always attended these meetings, a place of honor was available, and for those students who had long been absent, the Sheikh had a great longing. As such, Sheikh 'Idul Ya'qubi mentioned how the Prophet Muhammad SAW had spoken with his companions. The important lesson conveyed by the Prophet Muhammad was that he longed for the companions that would come after his death and would not be able to see him. This situation could be overcome if his surviving companions would continue to practice and teach what the Prophet Muhammad SAW had felt, taught, said, and done. As such, his subsequent companions would be able to see the Prophet Muhammad even after his death. One day, during another meeting, Sheikh 'Idul Ya'qubi discussed the relationship between the Prophet Muhammad and his companions:

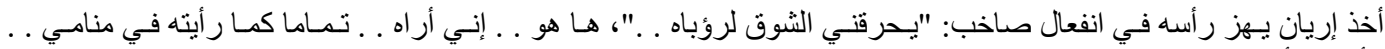

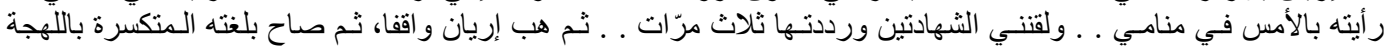
العربية، ذات اللكنة الأجنبية: "أشهد أن لا إله إلا الله، و أشهر أن مـحمّدا رسول الله" (الكيلانسي، 2001: 101-102).

Translation: Iryan began to shake his head. He then said, "My longing to see the Prophet Muhammad has set my heart on fire. I have truly seen the Prophet Muhammad. Perfectly I have seen Him in my dream. He has guided me in reciting the two sentences of the Shahadah, and I followed Him, and repeated it three times." Iryan stood tall and said, despite great hardship, "I testify that there is no god but God. Muhammad is the messenger of God" (al-Kîlāniy, 2001: 101-102).

This textual evidence indicates that Iryan had long studied Islam, and had not only learned its teachings, but also lived them; he had also observed what had been felt, thought, said, and done by 
the Prophet Muhammad. As such, Iryan could clearly see the Prophet Muhammad in his dreams. Muslims who have reached the level of mukmin, who had completely submitted themselves to the will of Allah, live as though their lives are guided by the Prophet Muhammad, and thus feel close to Him. Conversely, the Prophet Muhammad feels close to all of his followers, even though he has died. In his dream, Iryan also clearly saw the Prophet Muhammad and was guided in reciting the two sentences of the Shahadah. Thus did Iryan become a Muslim, as shown in the following quote:

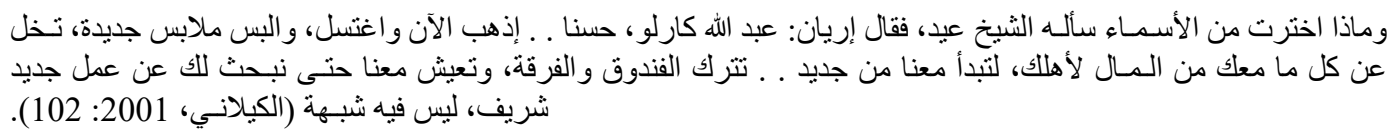

Translation: Sheikh 'Id asked Iryan: "What name do you choose?" Iryan answered, "Abdullah Carlou". "Good," said the Sheikh. "(In that case,) go now and clean yourself. Wear new clothes, abandon all you have brought with you, and begin a new life with us. Leave your lodgings and your band. Live with us as you seek better work, that which contains no subhat (between halal and haraam) (al-Kīlāniy, 2001:102).

This textual evidence shows that, after Iryan spoke the two sentences of the shahada and became a Muslim, Sheikh 'Idul Ya'qubi asked him to choose a good name. Iryan chose to change his name to "Abdullah Carlou"; the name Carlou was a patronym, taken from his father's name, while Abdullah meant "servant of God who follows His commands and avoids His prohibitions". Often, Westerners who convert to Islam have difficulty finding employment. As such, Sheikh 'Idul Ya'qubi asked Abdullah Carlou to leave his lodging and his music group, and to live with him as he sought employment that did not involve anything subhat.

Abdullah Carlou lived for some time with Sheikh 'Idul Ya'qubi, who found him a job as a driver with the Department of Education and Teaching. Although his wages were only a third of his income as a musician, Abdullah Carlou felt peace as it was all halal. Sheikh 'Idul Ya'qubi did not only teach Abdullah Carlou about Islam and its teachings; he guided him to the embrace of Islam, found him appropriate and halal work, and sought out a wife for him. The sheikh arranged for Abdullah Carlou to marry a Syrian-born Muslim teacher, who was also employed by the Department of Education and Teaching. This woman, Maisun by name, had olive skin and dressed and behaved modestly. After marrying Maisun, Abdullah Carlou embraced Islam and its teachings even more than Syamsi. As such, he had totally transformed, becoming truly eastern in his views and his ideas. He had abandoned Western culture, practicing Islam in a kāffah (total) manner (al-Kīlāniy, 2001). His life with his wife Maisun was one of peace, as shown in the following quote:

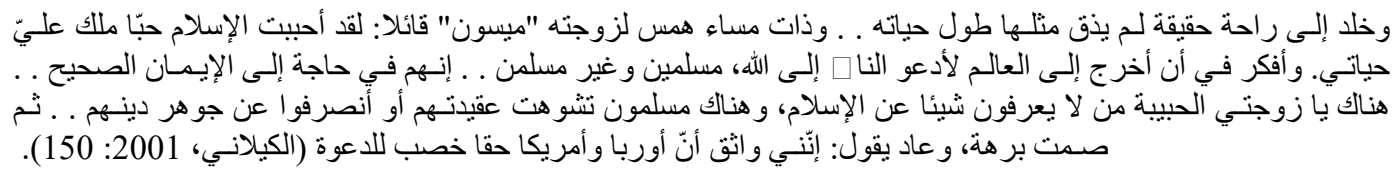

Translation: (Abdullah Carlou) felt a peace and harmony that he had never felt before. ... One evening, (Abdullah Carlou) whispered to his wife, Maisun, "I love Islam, which will guide me on my life's journey. I wish to leave the house and call people to Allah's way, be they Muslim or nonMuslim. ... All need the true faith... oh, my beloved wife, there are people out there who know 
nothing about Islam. There are also Muslims whose characters are tainted, who have turned away from the shining jewel of their religion's teachings." ... (Abdullah Carlou) was quiet for a moment, then continued: "I'm sure that Europe and America offer a fertile land for dakwah (proselytization)" (al-Kīlāniy, 2001:150).

The above textual evidence shows how Abdullah Carlou's heart found greater peace when he was with his wife, a devout Syrian-born Muslim woman named Maisun. His life with Maisun strengthened his resolve to practice the teachings of Islam, to carry out all of Allah's commandments, and to avoid violating all of his prohibitions, as well as to abandon Western culture and his habits as a musician. Abdullah Carlou sought to transform himself from a free-loving musician into a da' $\mathrm{i}$ (preacher) capable of guiding both Muslims and non-Muslims to the truth. Furthermore, he saw both Europe and America as places where he could teach others about Islam, guide them to the truth of Islam, and ensure they abandoned sin, even if he had to put his life at risk.

One day, Abdullah Carlou and his wife Maisun discussed their thoughts on their own pasts. Abdullah Carlou admitted that, when he had been a famous musician, he had fallen in love with a beautiful Christian woman named Sophia. He had later fallen in love with Syamsi, a beautiful Muslim singer and dancer from Dubai. He had been ready to marry both of these women, but they had both rejected him, saying that they desired to live freely and enjoy themselves, to have the freedom to travel wherever they wanted. Meanwhile, Maisun explained that her father had offered her a prospective husband. This man had been strong and brave, and focused on fighting all forms of kedhaliman (debauchery) and other things that went against Islamic teachings. However, Maisun had never met — or even seen - the man her father had chosen to be her husband. She only learned later that the young man her father had chosen for her had died a syāhid (martyr) while fighting for amar ma'ruf nahi munkar. As such, although Maisun had never seen the young man, she wanted to "wear a medal of honor on her chest, one covered in blood, as proof of her love for him" (al-Kīlanniy, 2001:160-161).

While Maisun was telling her story, Abdullah Carlou suddenly called out in pain, having been stabbed with a large knife. Maisun immediately took her husband to the hospital, where Abdullah Carlou continued to bleed as he laid upon her lap. While ensuring her husband's safety, Maisun saw a black, American-made car drive away. She saw two men and a woman in the car, but was unable to see their faces or the license plate number. Meanwhile, Sheikh 'Idul Ya'qubi urged all of his students to pray for Abdullah Carlou and visit him at the Ar-Rasyid Hospital.

After Abdullah Carlou was saved from death, those who came to see him were overjoyed, as he could continue his mission. As time passed, it was learned that the man who had stabbed Abdullah Carlou was Benito, his former bandmate. Benito and Sophia, Iryan's former lover, had been ordered by Pastor Carlou to bring him home or simply kill him for impugning the Pastor's good name and dignity as a priest. Iryan had become a true Muslim, and had begun preaching in Dubai and in Europe and America. His cultural mimicry had not been limited to simply changing his name from Iryan to Abdullah Carlou, but had also involved a transformation of his ideas and his behaviors.

After this attempted murder, Abdullah Carlou looked at Maisun, his devout and beautiful wife, and asked, "Am I now worthy of the medal of honor you have carried? Or are those who live to combat debauchery and sin unworthy of the same honors as those who have died as martyrs?" Maisun understood the true meaning of her husband's question. She looked at his face, showing the sincere love that came from the deepest wells of her heart. She was unable to say anything. She could only let her tears flow as she rested her head on her husband's body (al-Kīlāniy, 2001:161). 


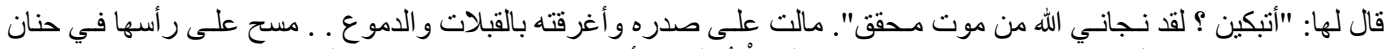

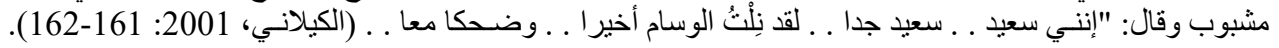

Translation: Abdullah Carlou asked his wife, Maisun "You cry? Allah has saved me from death." Maisun rested her head on her husband's chest. Maisun kissed her husband, her tears wetting his body. Abdullah Carlou stroked his wife's head lovingly and said, "Truly, I am happy. ... Very happy... finally I have earned my medal." They laughed together (al-Kīlāniy, 2001:161-162).

This textual evidence shows that Abdullah Carlou faced considerable difficulty, as well as extreme risks that almost led to his death, as a result of his cultural transformation (mimicry). However, for his struggles he received a happiness and joy that, though it could not be expressed with words, he felt together with his beautiful and devout Syrian-born wife.

\subsection{Cultural Hybridity}

Cultural hybridity is linked to the mutual influence of two different cultural identities (Hart, 2012; Stockhammer, 2018; Vauclair, Wilson, \& Fischer, 2014). In Najīb Al-Kīlāniy's novel ArRajulul-ladzī Āmana, the hybridity of Eastern and Western cultures is represented by the characters Syamsi and Mr. Shaqr.

In the novel, Syamsi is depicted as a Muslim woman from Dubai, an Eastern singer and dancer with long, black hair and great beauty, one whose fans readily fall in love with her. She is described as intelligent and capable of maintaining her Eastern culture, one that she had practiced since her youth. She worked in the entertainment industry, and from her performances she received a significant income that brought with it great temptation. She knew that working in the entertainment industry was risky, and that she could easily be led into temptation and even sin. With an income, as well as regular gifts from her fans, an entertainer could easily be led astray by worldly pleasures. She could travel freely, drink in pubs, shop in malls, and do various activities with men. This is shown in the following quotation:

وفوجىء بصقر يقف متباطئا ويقول: هل ستأتين معي لسوق "الغرير" لشر اء ما يلز مك . ـ هبت شـمس و اقفة في سعادة وحمـاسة،

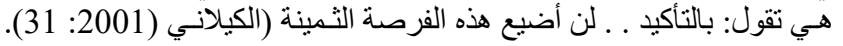

Translation: Suddenly, she was surprised by Mr. Shaqr, who stood slowly behind her and said, "Syamsi, would you come with me to the Gharir Market to buy the things you need?" Happily Syamsi stood and replied, "Certainly, and happily. I will not waste such a valuable opportunity" (alKîlāniy, 2001:31).

This textual evidence shows how Syamsi and Mr. Shaqr used their free time to shop at the market and purchase Syamsi's needs, with all of the expenses covered by her fan, Mr. Shaqr. At the time, Syamsi was speaking with Iryan, who had fallen in love with her. By agreeing to this materialist invitation, Syamsi showed her preference for Mr. Shaqr and her lack of interest in Iryan. This behavior, which emphasized Syamsi's own interests over others' feelings, was influenced by the Western culture embedded within the entertainment industry.

Syamsi's behavior brought great pain, anger, and jealousy to Iryan. He found that, behind her seeming humility, Syamsi brought him the same sorrow and pain as his former lover Sophia. Iryan could accept such behavior from women such as Sophia, who had been raised in Europe and shaped 
by Western culture. However, despite being a Dubai-born Muslim woman, Syamsi behaved the same, acting on her desires without considering her conscience.

Meanwhile, Mr. Shaqr was a handsome young man, a wealthy merchant from Dubai who had an international business network that reached England, Japan, Singapore, and America but had never been to Rome. With his wealth, he could tempt any woman-including Syamsi-to seek out pleasure with him. Syamsi was his favorite dancer and singer, and as such he enjoyed taking her out, as seen in the following quote:

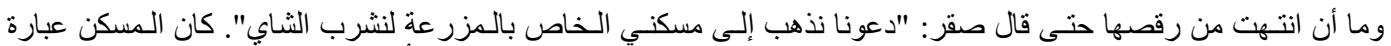

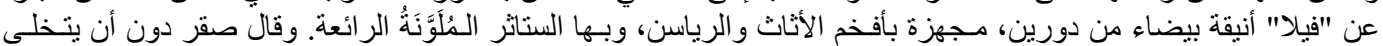

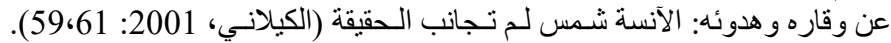

Translation: Even before Syamsi finished dancing, Mr. Shaqr invited her. "Come with me. Let's go to my estate and enjoy some tea. It is like a villa, beautiful... white as a durian, filled with luxurious and expensive goods, as well as colorful curtains and enticing fragrances." Mr. Shaqr said calmly. Syamsi was a girl who had never forgotten the truth of religion (al-Kīlāniy, 2001:59; 61).

This textual evidence shows that Mr. Shaqr's interest in the beautiful dancer drove him to speak with Syamsi at her performance venue, to use his wealth and power to draw Syamsi to his special estate to relax and drink tea. He imagined that he could have fun and enjoy himself with Syamsi, the beautiful dancer and singer. At the estate, Mr. Shaqr and Syamsi would be surrounded by worldly luxury, freedom, and pleasure, all of which Iryan was learning to avoid.

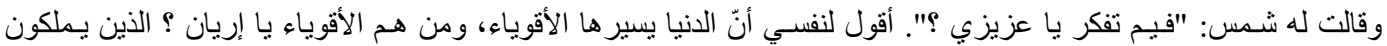

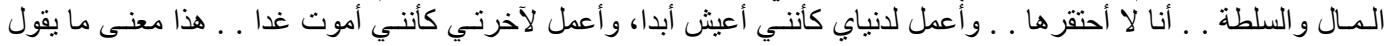

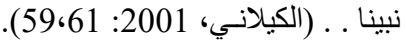

Translation: Syamsi asked Iryan, "What are you thinking about, love? I only told myself that this world is made for those with strength." (Syamsi asked again in a low voice), "Who is strong, Iryan?" (Iryan answered): Those with wealth and power." (Mr. Shaqr interrupted), "I have no power or wealth. I work for the world as though I will live in it forever, and I also work for the afterlife as if I will die tomorrow. For that is the hadith of the Prophet Muhammad SAW" (al-Kīlāniy, 2001:59; 61).

This textual data explores Iryan's idea that the world is controlled solely by those with money and those with power. Such an experience was had by Mr. Shaqr. With his wealth, Mr. Shaqr was able to easily tempt the beautiful dancer Syamsi and invite her to join him on pleasure trips. Meanwhile, Syamsi was able to use her beauty and her fame as an entertainer to find worldly pleasures together with her wealthy fans. In other words, both Mr. Shaqr and Syamsi lived for worldly pleasures. Even though Mr. Shaqr referenced the hadith of the Prophet Muhammad SAW, claiming to work hard both for worldly and heavenly life, his behavior showed that he put greater emphasis on having fun with Syamsi. 


\section{Conclusion}

From the above discussion, it may be concluded that the transformation of Western culture to Eastern culture (mimicry) is represented in Najīb Al-Kīlāniy's novel Ar-Rajulul-ladzī Āmana by the character Iryan. In the novel, Iryan is described as an Italian musician who is the son of a famed pastor, Carlou. From youth, Iryan learned Christian teachings, and as a musician he was strongly influenced by the Western culture that surrounded him. At first, Iryan was in a relationship with Sophia, a beautiful Roman woman who lived only for pleasure. She drank alcohol in pubs, displayed her body, and interacted freely with men despite being in a relationship.

Iryan chose to seek out new experiences as a musician, choosing to perform in Dubai. For this, he left his lover Sophia, who refused to join him in Dubai or marry him. In Dubai, Iryan met a gorgeous dancer named Syamsi. Iryan fell in love with her, but could not marry her because he was Christian while Syamsi was Muslim. Syamsi told Iryan that, to marry her, he must first embrace Islam.

To ensure that he could win the love and hand of this Dubai beauty, Iryan chose to study Islam under Sheikh Jalaluddin, Sheikh 'Idul Husaini, and Sheikh 'Idul Ya'qubi. Iryan dedicated himself to studying the teachings of Islam and became a devout Muslim, ultimately changing his name to Abdullah Carlou. He later took Maisun, a gorgeous Syrian woman, as his wife. Abdullah Carlou led a Muslim household and became a famed preacher, spreading Islamic teachings and Eastern culture both in the East (Dubai) and in the West (Europe and America). It is here that the cultural transformation represented by Iryan is clearest. He went from a Christian to a Muslim, changed his name, and abandoned music to become a preacher.

Meanwhile, a hybridity of Western and Eastern culture is represented in Najīb Al-Kīlāniy's novel Ar-Rajulul-ladzī Āmana through the characters Syamsi and Mr. Shaqr. In the novel, Syamsi is described as a beautiful dancer and singer from Dubai, one who attracts fans to her every performance. As an entertainer renowned for her beauty, Syamsi lived as Westerners did. She too displayed her body, wearing transparent clothes to show her every curve; at times, she would drink alcohol and enjoy the company of men. However, as a Muslim, Syamsi would watch herself with her fans. She would fast, and - when she remembered - she would also pray and practice the other teachings of Islam. Similarly, Mr. Shaqr is depicted as a respected, dignified, and wealthy merchant, one of the richest men in Dubai. Over the course of the novel, Mr. Shaqr frequently invites Syamsi to travel with him, to shop, or to visit his villa. In brief, he lives only to enjoy the company of his favorite singer. Although Mr. Shaqr claims to live according to the hadiths of the Prophet Muhammad SAW, i.e. by working hard for worldly and heavenly life, his everyday behaviors are those of Westerners. From this discussion, it can be concluded that Syamsi and Mr. Shaqr lived as though they were westerners. Nonetheless, as Muslims, Syamsi and Mr. Shaqr maintained the decorum and etiquette expected of their religious and cultural teachings. As such, Syamsi and Mr. Shaqr represent cultural hybridity.

The extent of Eastern (Islamic) culture's influence on Western (Christian) culture can be seen, for example, in the religious scholars' ability to learn Islam through Arabic-language media and to express their knowledge in other languages (English, Greek, German, Spanish, Japanese, etc.); as such, they can teach mu'allaf (persons who have converted to Islam and seek to understand the religion's teachings) about Islam in their native tongues. Through their command of such languages, 
these sheikhs can ensure that Islam's teachings can be learned and practiced by persons of all cultural backgrounds, no matter where they live.

\section{References}

[1] Abul-'Azm, Thal'at 'Abdul-'Azīz. 2015. Adabun mā ba'dal-Isti 'māri, wa NazhariyatuhunNaqdiyyah. Ath-Thab’atul-Ūlā. An-Nāsyir, 'Ainun Lid-Dirāsāt wal-Buchūtsil-Insāniyyah walIjtimā'iyyah.

[2] Afri Wita. 2013. "Punakawan Menggugat Pe-Liyan-An: Analisis Wacana Poskolonial Pada Novel Puragabaya". Humaniora. https://doi.org/10.22146/jh.v25i1.1813.

[3] Albertus Prasojo. 2015. "Konstruksi Identitas Dalam Sastra Terjemahan Eropa Era 1900-1930 dan Reaksinya Dalam Sastra Indonesia". Humaniora. https://doi.org/10.22146/jh.v27i3.10588.

[4] Al-Kīlāniy, Najīb. 2001. Ar-Rajulul-ladzī Āmana. Ath-Thab'atuts-Tsālitsah. Mu'asasatur-Risālah Nāsyirun, Beirut.

[5] Al-K̄̄lāniy, Najīb. 2006. Mudakkirātud-Duktūr Najīb Al-Kīlāniy. Al-Juz’ul-Awwal, KitābulMukhtār, Egypt.

[6] Dwi Sulistyorini, Bani Sudardi, M. W. Warto. 2017. "Cultural Commodification: Representation of the Pesarean of Mount Kawi as Cultural Tourism in Indonesian Mass Media". ISLLAC Journal of Intensive Studies on Language, Literature, Art, and Culture, 1(1), 19-35.

[7] Bhabha, Homi K. 1994. The Location of Culture. Routledge, New York.

[8] Kasiyan. 2003. "Revitalisasi Dialektika Pliralitas Budaya Global Dalam Perspekif Poskolonial". Humaniora. https://doi.org/10.22146/jh.v15i1.776.

[9] Chen, L. C. (2014). What's the cultural difference between the West and the East? The Consumption of Popular "Cute" Games in the Taiwanese Market. New Media and Society, 16(6), 1018-1033. https://doi.org/10.1177/1461444813497555

[10] Hart, J. 2012. Hybridity and Being Between Cultures. Canadian Review of Comparative Literature, 139-151.

[11] Lu, L. U. O. 2001. Cultural Values and Happiness : An East - West Dialogue. The Journal of Social Psychology, 141(September), 4. https://doi.org/10.1080/002245401096-00566

[12] Maeda, M. 2009. Education and Cultural Hybridity: What Cultural Values should be Imparted to Students in Kenya ? Compare, 39(3), 335-348. https://doi.org/10. 1080/03057920802351713

[13] Mona El-Sherif. 2018. "Rethinking the Eurocentric Gaze in Narratives of Urban Modernity: the Shaykh, the Flâneur, and the Orientalist in Takhlīṣ al-Ibrīz and 'Alam al-Dīn". Middle Eastern Literature Jurnal. https://doi.org/10.1080/ 1475262X.2018.1492190.

[14] Moriguchi, Y., Evans, A. D., Hiraki, K., Itakura, S., \& Lee, K. (2012). Child Cultural Differences in the Development of Cognitive Shifting: East - West Comparison. Journal of Experimental Child Psychology, 111(2), 156-163. https://doi.org/10. 1016/j.jecp.2011.09.001

[15] Raj, Prayer Elmo. 2014. Postcolonial Literature, Hybridity and Culture. International Journal of Humanities and Social Sciences Studies.

[16] Shabrina An Adzhani. 2014. "Konstruksi Ruang Kota Poskolonial dan Respons Spasial dalam Novel The Kite Runner Karya Khaled Hosseini". Poetika. https://doi.org/10.22146/poetika.10418.

[17] Singh, Amardeep. 2009. Mimicry and Hybridity in Plain English. Associate Professor of English at Lehigh University. http:// www.lehigh.edul amsp/blog.html.

[18] Stockhammer, P. W. (2018). Conceptualizing Cultural Hybridization: A Transdisciplinary Approach. London, New York: Springer Heidelberg Dordrecht. https://doi.org/ 10.1007/978-3-642-21846-0

[19] Suyono Suyatno. 2012. "Rivalitas Tradisi Modernitas dalam Perspektif Poskolonial: Telaah atas Sejumlah Sajak Abad 20". Humaniora, https://doi.org/10.22146/ jh.v24i1.1040. 
[20] Vauclair, C. M., Wilson, M., \& Fischer, R. (2014). Cultural Conceptions of Morality: Examining Laypeople's Associations of Moral Character. Journal of Moral Education, 43(1), 54-74. https://doi.org/10.1080/03057240.2013.873365. 